\title{
Synthesis and Properties of Polyurethane Foams Obtained from Cassava Starch and Rice by-products
}

\author{
Claudia V. Vargas-Gutiérrez ${ }^{1}$, Hans Th. Castro-Salazar ${ }^{1}$ and Carlos A. Ríos-Reyes ${ }^{2 *}$ \\ ${ }^{1}$ Grupo de Investigaciones Ambientales del Huila (GIAH), Escuela de Ingeniería Ambiental, Corporación \\ Universitaria del Huila, Neiva, Colombia. \\ ${ }^{2}$ Grupo de Investigación en Geología Básica y Aplicada, GIGBA, Escuela de Geología, Universidad \\ Industrial de Santander, Bucaramanga, Colombia.
}

\begin{abstract}
* Corresponding author: Carlos A. Ríos-Reyes, Escuela de Geología, Universidad Industrial de Santander, Bucaramanga, Colombia, phone: + 577 634400, Ext: 3514, e-mail: carios@uis.edu.co
\end{abstract}

Received July 31 ${ }^{\text {st }}$, 2017; Accepted February $9^{\text {th }}, 2018$.

DOI: http://dx.doi.org/10.29356/jmcs.v62i3.778

\begin{abstract}
The Huila department (Colombia) has a continuous growth in the production of rice, being the second largest national producer with increased production of rice in the central part of the country with yields of $6.8 \mathrm{~T} / \mathrm{Ha}$ in the first half of 2014, resulting in a large accumulation of waste and inadequate use and management of water resources. The by-products generated in the post-harvest, such as chaff, straw and rice husks, end up being used as fuel with no additional advantage. In this work there were prepared and characterized polyurethane foams obtained by cassava starch and rice biomass mixture. Polyurethane foams are commercially used in horticulture and agriculture, which becomes an alternative solution for the use of biomass. The use of the byproducts of rice in the preparation of polyurethane foams in horticulture and agriculture purposes is proposed here. The polyurethane foams were obtained from mixtures of cassava starch, rice biomass previously treated with $0.1 \mathrm{~N} \mathrm{NaOH}$, and commercial methylene diphenyl diisocyanate and polyol. The endpoint was the cassava starch and rice biomass wt.\% used in the mix. Density, water absorption and hardness of polyurethane foams were determined, and they were characterized by infrared spectroscopy and scanning electron microscopy. $33-44 \times 10^{-3} \mathrm{~g} / \mathrm{cm}^{3}$ y $26-46 \times 10^{-3} \mathrm{~g} / \mathrm{cm}^{3}$ were the values of densities obtained for cassava starch- and cassava starch and rice biomass-based polyurethane foams, respectively, and they reached a value of water absorption until $353.0 \%$. Infrared spectra confirmed the N-H functional groups $\left(3301 \mathrm{~cm}^{-1}\right)$ and $\mathrm{CO}\left(1309 \mathrm{~cm}^{-1}\right)$ characteristic of the polymer. The cassava starch- and cassava starch and rice biomass-based polyurethane foams got smaller pores $(114.4 \mu \mathrm{m})$ and $(132-580 \mu \mathrm{m})$, respectively, compared to pores obtained from commercial foams $(1092 \mu \mathrm{m})$.
\end{abstract}

Keywords: Foams; polyurethane; rice biomass; cassava starch; by-products.

Resumen. El departamento del Huila (Colombia) tiene un crecimiento continuo en la producción de cultivos de arroz, siendo el segundo productor a nivel nacional con la mayor producción de arroz de la zona centro del país con rendimientos del $6.8 \mathrm{~T} / \mathrm{Ha}$ en el primer semestre del 2014, lo que genera una gran acumulación de residuos y un uso y manejo no adecuado del recurso hídrico. Los subproductos que se generan en la postcosecha, tales como tamo, paja y cascarilla del arroz, terminan siendo usados como combustibles, sin ningún aprovechamiento adicional. En este trabajo se prepararon y caracterizaron espumas de poliuretano a partir de mezclas de almidón de yuca y biomasa del arroz. Las espumas de poliuretano se usan comercialmente en horticultura y agricultura, como chaquetas retenedoras de agua, agroquímicos y plaguicidas. En esta región del país se cultivan grandes hectáreas de arroz de riego, usando el agua proveniente de quebradas y ríos aledaños y acumulando grandes cantidades de subproductos, tales como paja, tamo y cascarilla del arroz. Las espumas de poliuretano se obtuvieron a partir de mezclas de almidón de yuca y biomasa de arroz tratada previamente con $\mathrm{NaOH} 0.1 \mathrm{~N}$, and metileno difenil diisocianato y poliol comercial. 
La variable de estudio fue el $\% \mathrm{p} / \mathrm{p}$ de almidón de yuca y biomasa de arroz usada en la mezcla. A las espumas de poliuretano se les determinó su densidad, absorción y dureza, y se caracterizaron por espectroscopía de infrarrojo y microscopía electrónica de barrido. Las espumas de poliuretano preparadas a partir de almidón de yuca y de almidón de yuca y biomasa de arroz obtuvieron valores de densidad fueron $33-44 \times 10^{-3} \mathrm{~g} / \mathrm{cm}^{3}$ y $26-$ $46 \times 10^{-3} \mathrm{~g} / \mathrm{cm}^{3}$, respectivamente, alcanzando porcentajes de absorción de hasta $353.0 \%$. Los espectros de infrarrojo confirmaron los grupos funcionales $\mathrm{N}-\mathrm{H}\left(3301 \mathrm{~cm}^{-1}\right)$ y C-O $\left(1309 \mathrm{~cm}^{-1}\right)$, característicos del polímero. Las espumas de poliuretano a base de almidón de yuca y de almidón de yuca y biomasa de arroz, obtuvieron los poros más pequeños $(114.4 \mu \mathrm{m})$ y $(132-580 \mu \mathrm{m})$, respectivamente, en comparación con las espumas de poliuretano comerciales $(1092 \mu \mathrm{m})$.

Palabras clave: Espumas; poliuretano; biomasa de arroz; almidón de yuca; subproductos.

\section{Introduction}

Polyurethanes constitute an interesting family of synthetic polymers with a specific molecular design for a variety of products, such as foams, medical devices, sports goods, adhesives, sealants, coatings, tough solids, elastomers, etc. [1-6]. They are synthesized through a polyaddition reaction between a polyisocyanate (a polymeric molecule with two or more isocyanate groups, such as methylene diphenyl diisocyanate (MDI)) and a polyol (a polymer with two or more reactive hydroxyl groups) [7]. Polyurethane foams (PUFs) are a class of lightweight porous materials with enormous interest because of their specific properties and potential application in several fields [8], and they can be classified into two major categories: flexible and rigid foams [6]. Currently, the polyurethane (PU) industry is still heavily petroleum-dependent because its two major feedstocks, polyols and isocyanates derive entirely from it; however, due to the uncertainty about the cost of petroleum in the future, as well as the need to move toward more environmentally friendly feedstocks, many recent efforts have been focused on replacing all or a portion of the conventional petroleum-based polyols by counterparts obtained from renewable resources [6]. Various polysaccharides, such as starch [9], soybean [10], alginic acid [11], palm [12], sugar-cane bagasse [13], lignin [14], cork [15] or coffee grounds [16] have been employed to obtain products, which can be used as the polyol component in the production of PUFs as a particular interesting strategy. Polyols can vary in equivalent weight, functionality, and the degree of rigidity or flexibility contributed by the different chain units in the polyurethane [17]. According to Romaškevič [17], PUFs can be classified into flexible, semi-flexible and rigid types; the flexible type show relatively lowbearing properties with high recovery properties, similar to a coiled metal spring, while the rigid type displays high load-bearing properties and a subsequent cellular collapse and lack of recovery; the semiflexible type possesses a mixture of these characteristics.

Colombia ranks world's $25^{\text {th }}$ place among rice-producing countries and is third in Latin America after Brazil and Peru. Rice is the fourth most important crop after sugarcane, oil palm fruits and plantains. Rice production represents $10 \%$ of the value of agricultural activity and is a basic food for the poorest people in the country. Colombia's rice production in 2016 is expected to be about 1.95 million metric tons (4.60 ton/ha) due to improved pest control, variety use, and crop management. Rice farming is concentrated in the central zone, with average annual production of 780.333 ton during the last 20 years. Tolima, Huila, Meta, and Casanare departments are responsible for $72 \%$ of national rice production, with Huila department as the second national producer having the highest productivity of rice with yields of 6.8 ton/ha in the first half of 2015 as recorded by the Departamento Administrativo Nacional de Estadística (DANE) [18].

Environmental pollution from agricultural rice by-products, such as rice husk has become a serious problem in the Huila department due to the volume generated after harvest of the crop. Sometimes these residues are used as fertilizers and fuel, or they are thrown into rivers or landfills and, in the worst case, burned, generating air emissions from high concentrations of contaminants, mainly in form of $\mathrm{CO}_{2}$. Additionally, the rice crops use large amounts of water, which often contribute to leaching of contaminants in soil. One way to reduce water consumption is the use of polyurethane foams, which are used as "jackets" in agriculture and horticulture, trapping water, fertilizers and pesticides used on crops. The main problem of these polymers is their slow biodegradation. Recent advancements in development of new polyurethanes foams using renewable feed stock have been showed [19]. In the present study, commercial polyurethane foams were modified using mixtures of rice biomass and cassava starch as the polyol component, contributing 
to the mitigation of the environmental impact. The composition of the mixtures in the foams was changed to analyze how it influences in its properties and the resulting foams were characterized by several chemical physical methods.

\section{Experimental procedure}

\section{Materials}

The materials used in this study consisted of cassava starch and rice biomass, water, and Commercial MDI (95\% of 4,4'-MDI, Methylene-Diphenyl Diisocyanate) and polyether polyol mixture included water and the catalyst that was Jeffcat ZF-22 (triethylene diamine). The collection of biomass harvesting rice (husk, straw and chaff) was conducted in a farm located on the road to the municipality of Santa María, department of Huila, Colombia. Cassava was obtained from a supermarket.

\section{Preparation of PUFs}

The biomass harvesting rice (husk, straw and chaff) was crushed in the laboratory, dried in an oven for 2 hours and ground using a mill FZ 102, with a $500 \mu \mathrm{m}$ pore size grids. The treatment of biomass was performed with an alkaline solution ( $\left.\mathrm{NaOH} 0.1 \mathrm{~mol}^{\mathrm{L}} \mathrm{L}^{-1}\right)$ for 2 hours under stirring and heating conditions. The alkali treatment of the biomass was a pretreatment to separate the lignin and ensure a greater availability of the number of hydroxyl groups. The resulting product was filtered and dried in an oven at $100^{\circ} \mathrm{C}$ for 3 hours. Cassava starch was obtained from cassava (Manihot sculenta) following the procedure described by Salcedo et al. [20]. Table 1 reports the details of the mixture compositions of rice biomass, cassava starch, commercial MDI and polyol for preparation of PUFs. All samples were prepared three times. The PUFs produced in this study were characterized and compared with commercial PUFs.

Table 1. Details of mix composition of rice biomass and cassava starch, MDI and polyol for preparation of PUFs.

\begin{tabular}{ccccccc}
\hline PUFs & $\begin{array}{c}\text { Cassava starch* } \\
\text { wt.\% }\end{array}$ & $\begin{array}{c}\text { Rice biomass* } \\
\text { wt.\% }\end{array}$ & $\begin{array}{c}\text { Cassava } \\
\text { starch (g) }\end{array}$ & $\begin{array}{c}\text { Rice biomass } \\
\text { (g) }\end{array}$ & MDI (g) & $\begin{array}{c}\text { Polyol } \\
\text { mixture } \\
\text { (g) }\end{array}$ \\
\hline CS1 & 5.595 & 0.000 & 0.5 & 0.0 & 5.0 & 5.0 \\
CS2 & 9.030 & 0.000 & 1.0 & 0.0 & 5.0 & 5.0 \\
CS3 & 13.190 & 0.000 & 1.5 & 0.0 & 5.0 & 5.0 \\
CS4 & 16.700 & 0.000 & 2.0 & 0.0 & 5.0 & 5.0 \\
CS5 & 19.660 & 0.000 & 2.5 & 0.0 & 5.0 & 5.0 \\
CS6 & 23.110 & 0.000 & 3.0 & 0.0 & 5.0 & 5.0 \\
CSRB1 & 0.000 & 4.196 & 0.5 & 0.5 & 5.0 & 5.0 \\
CSRB2 & 0.000 & 8.264 & 0.5 & 1.0 & 5.0 & 5.0 \\
CSRB3 & 0.000 & 11.810 & 0.5 & 1.5 & 5.0 & 5.0 \\
CSRB4 & 0.000 & 13.440 & 0.5 & 2.0 & 5.0 & 5.0 \\
CSRB5 & 0.000 & 15.780 & 0.5 & 2.5 & 5.0 & 5.0 \\
CSRB6 & 0.000 & 18.070 & 0.5 & 3.0 & 5.0 & 5.0 \\
\hline
\end{tabular}

*Mean values

\section{Characterization of PUFs}

The density of PUFs was determined according to the ASTM D 3574-11 standard [21]. PUFs specimens $\left(10 \times 10 \times 10 \mathrm{~mm}^{3}\right)$ were cut and weighed, and their volume calculated by measuring their dimensions. The density was calculated to room temperature dividing the weight of the specimens by the calculated volume using the eq. (1):

$$
\text { (1) } \rho=W / V
$$


where $W$ is the weight and $V$ is the volume of the cube. All calculations were done three times. The density of the commercial PUF is $51 \times 10^{-3} \pm 2 \mathrm{~g} / \mathrm{cm}^{3}$.

The water absorption of the PUFs was determined according to the ASTM D570-98 (2010) standard [22]. Small PUF-based discs were immersed in water for 2 hours and weighed on a wet basis. Then, they were introduced into an oven for 2 hours and weighed on a dry basis. The percentage of water absorption of the polyurethane foam was $303.6 \%$. The content of water absorbed by PUFs was determined according to eq. (2):

(2) water absorption $\%=$ (wet weight - dry weight) $\mathrm{x} 100$ / dry weight

The mean values of densities and water absorption were the average of three measurements.

Hardness of PUFs was determined according to the ASTM D2240-00 (2010) standard [23], using a digital Starrett Shore A durometer Model No. 3805 B at room temperature $\left(30{ }^{\circ} \mathrm{C}\right)$. The needle was applied in different parts of the sample and the final result was the average of three repetitions.

The FTIR spectra of PUFs were obtained by Fourier transform infrared (FTIR) spectroscopy using a BRUKER TENSOR 27 spectrometer. All data were recorded at $20^{\circ} \mathrm{C}$, in the $4000-400 \mathrm{~cm}^{-1}$ range by accumulating 32 scans. A BRUKER ATR PLATINUM cell was used. PUFs were attached to a sample holder using double sided carbon tape and then they were coated by a thin layer of carbon.

Secondary electron (SE) imaging and EDS analysis of garnet were performed in a FEI QUANTA 650 field emission gun environmental scanning electron microscope (FEG ESEM) under the following analytical conditions: magnification $=200 \mathrm{x}, \mathrm{WD}=9.2-9.8 \mathrm{~mm}, \mathrm{HFW}=1.49 \mathrm{~mm}, \mathrm{HV}=20 \mathrm{kV}$, signal $=\mathrm{BS}$ in $\mathrm{Z}$ CONT mode, detector $=\mathrm{BSED}$, EDS Detector EDAX APOLO X with resolution of $126.1 \mathrm{eV}$ (in. Mn $\mathrm{K} \alpha$ ). ESEM images were used to determine the average cells size of the PUFs, and cell diameter was obtained by inspecting visually several porous cells on the surface of the PUFs.

\section{Results and discussion}

\section{Density and water absorption of cassava starch- and cassava starch and rice biomass-based PUFs}

Density and water absorption values of cassava starch- and cassava starch and rice biomass-based PUFs are presented in Table 2.

Table 2. Density and water absorption of cassava starch- and cassava starch and rice biomass-based PUFs according to the dose of rice biomass and cassava starch (wt.\%).

\begin{tabular}{|c|c|c|c|}
\hline PUF & $\mathbf{w t . \%}$ & $\begin{array}{c}\text { Density* } \\
\left(\mathbf{x 1 0}^{-\mathbf{3}} \mathbf{g} / \mathbf{c m}^{\mathbf{3}}\right)\end{array}$ & Water absorption* \% \\
\hline CS1 & 5.595 & $39 \pm 1$ & $164.0 \pm 13.2$ \\
\hline CS2 & 9.030 & $35 \pm 1$ & $256.5 \pm 49.0$ \\
\hline CS3 & 13.190 & $33 \pm 1$ & $251.0 \pm 13.9$ \\
\hline CS4 & 16.700 & $38 \pm 2$ & $270.3 \pm 33.2$ \\
\hline CS5 & 19.660 & $36 \pm 1$ & $257.8 \pm 26.2$ \\
\hline CS6 & 23.110 & $44 \pm 2$ & $261.7 \pm 30.9$ \\
\hline CSRB1 & 4.196 & $26 \pm 2$ & $200.2 \pm 36.2$ \\
\hline CSRB2 & 8.264 & $30 \pm 4$ & $223.2 \pm 41.2$ \\
\hline CSRB3 & 11.810 & $46 \pm 3$ & $353.0 \pm 41.0$ \\
\hline CSRB4 & 13.440 & $36 \pm 5$ & $176.1 \pm 38.8$ \\
\hline CSRB5 & 15.780 & $33 \pm 3$ & $267.3 \pm 43.7$ \\
\hline CSRB1 & 18.070 & $40 \pm 5$ & $331.1 \pm 45.6$ \\
\hline
\end{tabular}

$*_{n}=3 ; \mathrm{x}+\sigma$ 
Table 2 shows the density of cassava starch-based PUFs, revealing that density increases with the concentration (wt. \%) of cassava starch, with the highest value $\left(44 \times 10^{-3} \mathrm{~g} / \mathrm{cm}^{3}\right)$ for CS6 and the lowest value $\left(33 \times 10^{-3} \mathrm{~g} / \mathrm{cm}^{3}\right)$ for CS3. Also, Fig. 1 illustrates the density of cassava starch and rice biomass-based PUFs, revealing that density increases with the concentration (wt. \%) of rice biomass and cassava starch, with the highest value $\left(46 \times 10^{-3} \mathrm{~g} / \mathrm{cm}^{3}\right)$ for CSRB3 and the lowest value $\left(26 \times 10^{-3} \mathrm{~g} / \mathrm{cm}^{3}\right)$ for CSRB1. The density values reported in this article are according to previous studies, i.e. using liquefied waste paper [24]. The densities obtained with rice biomass and cassava starch are similar to the density of commercial PUF. The density of PUFs may depend on the mass of expanded polymer, which in turn is related to the amount of the blowing agent used. However, filler incorporation can affect foam density, due to the interference of the solid particles with the nucleation step. The nucleation process is related to the number and the homogeneity of the gas micro-bubbles formed during the mechanical agitation of the unreacted liquid mixture.

Table 2 shows the percentage of water absorption of cassava starch-based PUFs, revealing that CS4 and CS1 showed the highest (270.3 \%) and lowest (164.0 \%) values, respectively. Besides, Table 2 include the percentage of water absorption of cassava starch and rice biomass-based PUFs, with the highest value $(331.1 \%)$ for CSRB6 and the lowest value $(115.4 \%)$ for CSRB4. These values are higher than the commercial PUF, it shows the increment obtained using rice by-products.

\section{Hardness of PUFs}

The hardness of the PUFs is shown in the Table 3. It was lower than that of commercial PUFs. The standard deviation values are significantly closer of the precision of durometer used in the measurements. According to the classification of shore hardness scales, the hardness values indicate an extra soft material very similar to the soft rubber bands. This indicates that different compositions of the cassava starch and rice biomass-based PUF's don't change the hardness of the material in a significant way

Table 3. Hardness of the PUFs.

\begin{tabular}{|c|c|}
\hline PUF & Hardness (HA)* \\
\hline CS1 & $2.8 \pm 0.6$ \\
\hline CS2 & $2.8 \pm 0.6$ \\
\hline CS3 & $3.8 \pm 0.6$ \\
\hline CS4 & $2.2 \pm 0.6$ \\
\hline CS5 & $1.8 \pm 0.6$ \\
\hline CS6 & $1.8 \pm 0.6$ \\
\hline CSRB1 & $2.2 \pm 0.6$ \\
\hline CSRB2 & $2.8 \pm 0.6$ \\
\hline CSRB3 & $2.2 \pm 0.6$ \\
\hline CSRB4 & $2.6 \pm 0.6$ \\
\hline CSRB5 & $1.8 \pm 0.6$ \\
\hline CSRB6 & $3.8 \pm 0.6$ \\
\hline *n $=3 ; \mathrm{x}+\sigma$ \\
Commercial PUF $4.2 \pm 0.6$ \\
\hline \multicolumn{2}{|c|}{}
\end{tabular}

\section{Fourier transform infrared (FTIR) spectroscopy}

The Fourier transform infrared spectroscopy spectrum of a typical cassava starch and rice biomassbased PUF is illustrated in Fig. 1. The characteristic absorption bands of the main functional groups of this polymer are depicted in Table 4. The spectrum shows eight (8) major absorption bands. The N-H functional group belonging to the amide group formed by the reaction between the diisocyanate and the polyol has two absorption bands at $3304 \mathrm{~cm}^{-1}$ (a small broad band attributed to the N-H stretching bond) and $1511 \mathrm{~cm}^{-1}$ (a large narrow band attributed to a bending out of the plane of the N-H stretching bond). $\mathrm{CH}_{2}$ and $\mathrm{CH}_{3}$ groups exhibit a broad band at $2925 \mathrm{~cm}^{-1}$ attributed to the $\mathrm{C}-\mathrm{H}$ stretching bond. The functional group $\mathrm{C}=\mathrm{O}$ of the amide or ester group, derived from the MDI and polyol, has a narrow and strong band attributed to the stretching vibration bond between the two atoms, confirming the polymerization reaction by the presence of bending vibrations out of the plane of the C-O-C bond at 1309, 1225 and $1081 \mathrm{~cm}^{-1}$. According to literature 
[25], the vibrational band at $2258 \mathrm{~cm}^{-1}$ can be attributed to the NCO group of the MDI, which does not react and remains as a residue. This band is not present in the FTIR spectrum and, therefore, we suggest that all the MDI reacted with the polyol.

Table 4. Characteristic absorption bands of a typical cassava starch and rice biomass-based PUF.

\begin{tabular}{|c|c|}
\hline Bands $\left(\mathrm{cm}^{-1}\right)$ & Attributions \\
\hline 3304 & $\mathrm{~N}-\mathrm{H}$ stretching vibrations \\
\hline 2925 & C-H stretching vibrations \\
\hline 1705 & $\mathrm{C}=\mathrm{O}$ stretching vibrations \\
\hline 1511 & $\mathrm{~N}-\mathrm{H}$ bending \\
\hline 1710 & $\mathrm{C}=\mathrm{O}$ bending \\
\hline 1412 & C-H deformations \\
\hline $1309,1225,1081$ & C-O-C scissor vibrations \\
\hline 815,739 & $\mathrm{C}-\mathrm{H}$ bending out plane \\
\hline
\end{tabular}

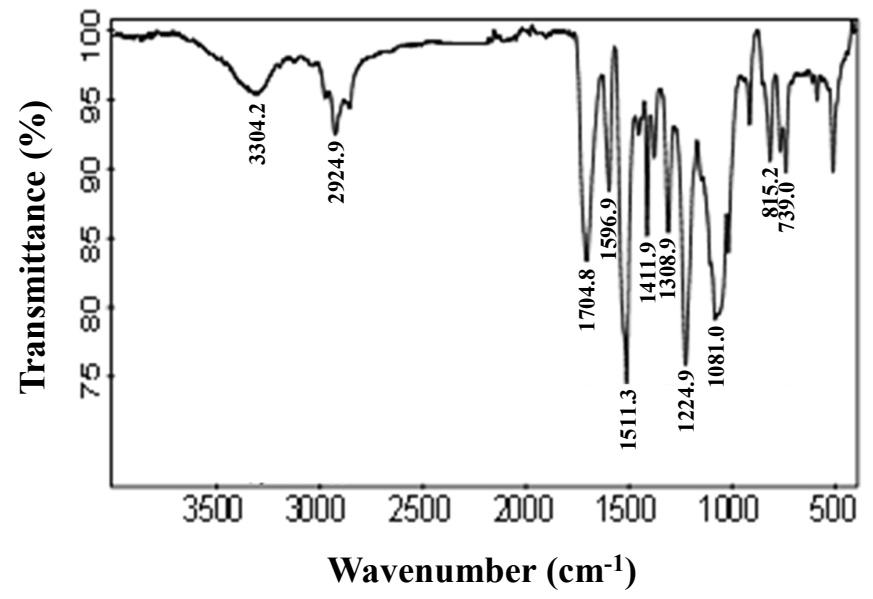

Fig. 1. FTIR spectrum of a typical cassava starch and rice biomass-based PUF.

\section{Field emission gun environmental scanning electron microscope (FEG ESEM)}

Fig. 2 shows the FEG ESEM micrographs of the surface of PUFs. They are characterized by a typical microcellular structure, which is produced by the internal generation or liberation of a gas in a fluid medium that simultaneously polymerizes while expanding in volume [26]. Furthermore, it is also noticeable that the cells are mainly opened. The modified PUFs show smaller pores than the commercial PUFs $(<200 \mu \mathrm{m})$. Some starch irregular granules without reaction is presented in the foams. The surface images reveal that some starch granules were broken into various parts and others were completely coated by a tightly adhering polyurethane layer.

Some gaps were found between the starch and polyurethane phases in which stretched polyurethane threads connect the two phases. This confirms the strong force between starch granules and polyurethane. The evidence of grafting with a polyurethane phase was also confirmed by $\mathrm{Ha}$ and Broecker [27]. A similar analysis is possible to do with rice biomass. However, the cellular structure of the unfilled foams is almost spherical and evenly distributed, with few broken cells and with smaller gap diameter than starch filled foams. It was possible by the incorporation of cellulose near of the nucleation sites of the cell formation of PUFs, as a higher number of cells start to nucleate at the same time, there is less gas available for their growth, and this 
leads to a decrease in the size of the cell. The results of cassava starch and rice biomass-based PUFs are according with those reported in the literature [28].
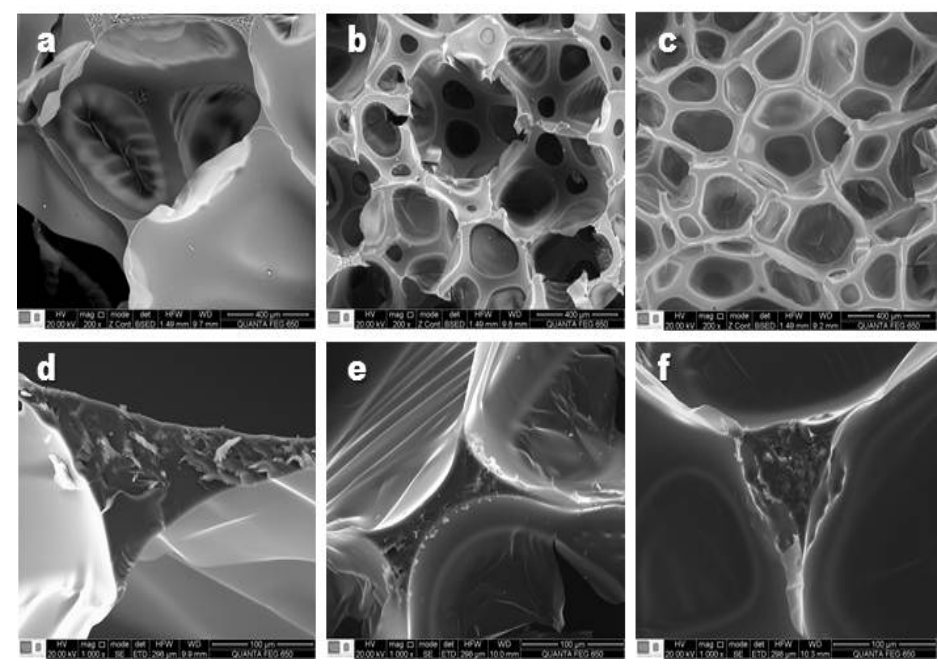

Fig. 2. SE images of the open cell structure of (a)-(d) commercial PUFs, (b)-(e) cassava starch-based PUFs and (c)-(f) cassava starch and rice biomass-based PUFs. Scale 100-400 $\mu \mathrm{m}$.

\section{Conclusions}

The method proposed in this research for the production of cassava starch and rice biomass-based PUFs produced technically viable results, taking into account that they show properties similar to commercial PUFs. In addition, the properties of PUFs can be modified with the biomass concentration obtained from rice. On the other hand, cassava starch- and cassava starch and rice biomass-based PUFs retain more water than the commercial PUFs, which makes them a viable alternative to promote an integrated management of water use on crops.

PUFs that showed the highest water absorption and density values were the CS6 $\left(44 \times 10^{-3} \pm 2 \mathrm{~g} / \mathrm{cm}^{3}\right)$ and the CSRB3 $\left(46 \times 10^{-3} \pm 3 \mathrm{~g} / \mathrm{cm}^{3}\right)$. The cassava starch and rice biomass-based PUFs showed smaller pore sizes compared to commercial PUFs. FTIR spectrum confirmed the $\mathrm{N}-\mathrm{H}\left(3301 \mathrm{~cm}^{-1}\right)$ and $\mathrm{C}-\mathrm{O}\left(1309 \mathrm{~cm}^{-1}\right)$ functional groups, which are characteristic of the polymer.

The search for new uses of agro-industrial by-products is a viable alternative for potential savings of energy, drinking water and essential raw materials to promote a sustainable development economy. This is the reason why the continuous generation of agro-industrial by-products, such as rice biomass (chaff, straw and husk) has driven the need in order to obtain PUFs as final products, replacing synthetic foams as those used as jackets in horticulture and agriculture.

\section{Acknowledgements}

This research is part of the undergraduate thesis by C.V. Vargas at Corporación Universitaria del Huila. We gratefully acknowledge the laboratorios of Microscopy and Spectroscopy of the Universidad Industrial de Santander at the Guatiguará Technology Park and their professional staff for assistance with SEM and FTIR data acquisition. The manuscript was greatly improved based on the critical and helpful reviews and comments by anonymous reviewers. We are most grateful to the above-named people and institutions for their support. 


\section{References}

1. Liaw, D.; Huang, C.; Liaw, B. Polymer 1998, 39(15), 3529-3535.

2. Li, S.; Vatanparast, R.; Lemmetyinen, H. Polymer 2000, 41(15), 5571-5576.

3. Kim, B.S.; Kim, B.K. J. Appl. Polym. Sci. 2005, 97(5), 1961-1969.

4. Cao, X.; Chang, P.R.; Huneault, M.A. Carbohydr. Polym. 2008, 71(1), 119-125.

5. Zia, K.M.; Barikani, M.; Zuber, M.; Bhatti, I.A.; Sheikh, M.A. Carbohydr. Polym. 2008, 74(2), 149158.

6. Gama, N.V.; Soares, B.; Freire, C.S.R.; Silva, R.; Neto, C.P.; Barros-Timmons, A.; Ferreira, A. Mater. Design 2015, 76 (1), 77-85.

7. Pan, X.; Saddler, J.N. Biotechnol. Biofuels 2013, 6(12), 1-10.

8. Ashida, K. Polyurethane and Related Foams Chemistry and Technology. Florida: Taylor \& Francis Group, 2007.

9. $\quad$ Kwon, O.; Yang, S.; Kim, D.; Park, J. J. Appl. Polym. 2006, 103 (3), 1544-1553.

10. Pechar, T.W.; Sohn, S.; Wilkes, G.L.; Ghosh, S.; Frazier, C.E.; Fornof, A.; Long, T.E. J. Appl. Polym. 2006, 101 (3), 1432-1443.

11. Yang, S.-R.; Kwon, O.-J.; Kim, D.-H.; Park J.-S. Fiber. Polym. 2007, 8 (3), 257-262.

12. Tanaka, R.; Hirose, S.; Hatakeyama H. Bioresour. Technol. 2008, 99 (9), 3810-3816.

13. Abdel Hakim, A.A.; Nassar, M.; Emam, A.; Sultan M. Mater. Chem. Phys. 2011, 129 (1-2), $301-307$.

14. Jin, Y.; Ruan, X.; Cheng, X.; Lü Q. Bioresour. Technol. 2011, 102 (3), 3581-3583.

15. Soares, B.; Gama, N.V.; Freire, C.S.R.; Barros-Timmons, A.; Brandão, I.; Silva, R.; Pascoal, C.; Ferreira, A. ACS Sustain. Chem. Eng. 2014, 2 (4), 846-854.

16. Soares, B.; Gama, N.V.; Freire, C.S.R.; Barros-Timmons, A.; Brandão, I.; Silva, R.; Pascoal, C.; Ferreira, A. J. Chem. Technol. Biotechnol. 2014, 90 (8), 250-275.

17. Romaškevič, T.; Budrienè, S.; Pielichowski, K.; Pielichowski, J. CHEMIJA 2006, 17(4), 74-89.

18. DANE. Encuesta Nacional de Arroz, Huila, 2015.

19. Zia, F.; Zia, K.M.; Zuber, M.; Kamal, Sh.; Aslam, N. Carbohydr. Polym. 2015, 134, 784-798.

20. Salcedo, J.G.; Montes, E.J.; Pajaro, J.L. Dyna 2009, 76, 121-130.

21. ASTM. Standard Test Method for Flexible Cellular Materials - Slab, Bonded, and Molded Urethane Foams D-3574-11. In: Annual book of ASTM, Vol 08, Philadelphia: ASTM, 2005.

22. ASTM. Standard Test Method for Water Absorption of Plastics D-570-98. In annual book of ASTM, Vol 08, Philadelphia: ASTM, 2010.

23. ASTM. Standard Test Method for Rubber Property- Durometer Hardness ASTM D-2240-05. In In annual book of ASTM, Vol 08, Philadelphia: ASTM, 2005.

24. Lee, S.H.; Teramoto, Y.; Shiraishi, N. J. Appl. Polym. 2001, 83 (7), 1482-1489.

25. Corcuera, M.A.; Rueda, L.; Fernandez d'Arlas, B.; Arbelaiz, A.; Marieta, C.; Mondragon, I.; Eceiza, A. Polym. Degrad. Stab. 2010, 95 (11), 2175, 2010.

26. Benning, C.J. Plastic Foams: the Physics and Chemistry of Product Performance and Process Technology, 1, Wiley, NY, 1969.

27. Ha, S.K.; Broecker, H.C. Polymer 2002, 43 (19), 5227-5234.

28. Ribero, V.; Mosiewicki, M.A.; Yoshida, M.I.; da Silva, M.C.; Stefani, P.M.; Marcovich, N.E. Polym. Test. 2013, 32 (2), 438-445. 